\title{
Perancangan Sistem Aplikasi Perpustakaan Berbasis Web Di SMK ITABA Menggunakan Framework Laravel
}

\author{
Winda Suryaning Ratri Pangastuti ${ }^{1 *}$, Budi Nugroho ${ }^{2}$, Made Hanindia Prami Swari ${ }^{3}$ \\ 1,2,3 (Informatika/Fakultas Ilmu Komputer, Universitas Pembangunan Nasional Veteran Jawa Timur) \\ budinugroho.if@upnjatim.ac.id \\ -madehanindia.fikeupnjatim.ac.id \\ *Corresponding author email: winda.ratrii@gmail.com
}

\begin{abstract}
Abstrak - Perpustakaan merupakan salah satu sumber tempat untuk belajar selain pembelajaran yang ada di dalam kelas, setiap sekolah mayoritas mempunyai ruangan perpustakaan untuk menunjang pembelajaran siswa agar mendapat informasi dan ilmu pengetahuan lebih banyak dari luar materi belajar yang disampaikan oleh guru-guru. Sama halnya dengan sekolah lain pada umumnya, SMK ITABA memiliki satu ruangan untuk dijadikan tempat perpustakaan sekolah. Pada perpustakaan di SMK ITABA menggunakan sistem perpustakaan yang manual dalam pengelolan data-data, seperti penyimpanan data perpustakaan yang belum terstruktur, pengolahan data peminjaman atau pengolahan data daftar buku yang masih menggunakan buku besar untuk penyimpanan. Oleh sebab itu, maka diperlukan upaya pengembangan dalam sistem perpustakaan yang ada di sekolah saat ini. Berdasarkan permasalahan tersebut, penelitian ini menghasilkan perancangan sistem aplikasi perpustakaan berbasis web untuk meningkatkan efisiensi kerja perpustakaan yang ada di SMK ITABA seperti mengelola data buku, mengelola data siswa, dan sirkulasi buku secara komputerisasi. Perancangan sistem aplikasi perpustakaan ini menggunakan framework Laravel, dan MySQL sebagai penampungan data.
\end{abstract}

Kata Kunci- Perancangan sistem, aplikasi perpustakaan, web, framework Laravel, MySQL.

\section{Pendahuluan}

SMK ITABA merupakan salah satu Sekolah Menengah Kejuruan yang berada di daerah Gedangan, lebih tepatnya berada di jalan RA. Mustika, Kelurahan Tebel, Kecamatan Gedangan, Kabupaten Sidoarjo, Provinsi Jawa Timur. Perpustakaan yang merupakan fasilitas yang disediakan oleh SMK ITABA yang juga sebagai salah satu komponen pengelola informasi, berencana memanfaatkan kemajuan tersebut. Pemanfaatan teknologi modern itu diharapkan dapat memperbaiki kinerja perpustakaan dan meningkatkan kunjungan dan kepuasan siswa maupun pengunjung lainnya. Permasalahan terletak pada metode yang digunakan perpustakaan yang masih menggunakan cara manual. Mulai dari siswa yang mencari terlebih dahulu kartu perpustakaannya sebelum menyerahkan buku kepada pustakawan untuk melakukan peminjaman ataupun pengembalian, sampai pustakawan yang menangani peminjaman dan pengembalian dengan cara menulis pada kartu buku yang diambil terlebih dahulu dari setiap buku yang akan dipinjam siswa yang kemudian disimpan sampai siswa mengembalikan buku, yang dari hal tersebut kartu buku baru bisa dimasukkan kembali pada buku. Dari permasalahan di atas, penulis mendapatkan gagasan dengan menyusun sebuah tugas akhir yang berjudul "PERANCANGAN SISTEM APLIKASI PERPUSTAKAAN BERBASIS WEB DI SMK ITABA MENGGUNAKAN FRAMEWORK LARAVEL". Dengan adanya sistem aplikasi perpustakaan ini penulis berharap bisa memberikan solusi untuk siswa yang melakukan peminjaman atau pengembalian buku tanpa harus mencari kartu keanggotaannya terlebih dahulu.

\section{TINJAUAN PUSTAKA}

\section{A. Framework}

Framework jika diartikan ke dalam Bahasa Indonesia, framework yang artinya adalah sebuah kerangka kerja, di sisi lain pengertian dari framework menurut Daqiqil (Daqiqil, 2011) framework adalah sebuah kerangka yang terstruktur konsepnya sehingga dapat membantu dalam pemecahan permasalahan atau isu-isu yang cukup kompleks.

\section{B. Laravel}

Pengertian dari framework merupakan sebuah konsep dasar yang membantu dalam menangani atau menyelesaikan masalah yang kompleks dalam pengerjaan proyek yang sedang kita kerjakan. Dapat disimpulkan bahwa framework merupakan suatu tempat atau kerangka dasar dalam pembuatan sebuah website. Oleh sebab itu dengan adanya kerangka tersebut, maka waktu yang kita gunakan dalam pembuatan sistem maupun website akan lebih efisien dan juga pembuatan website yang menggunakan framework dapat memudahkan kita dalam melakukan perbaikan (Naista, 2017).

\section{C. $\quad M y S Q L$}

MySQL adalah sebuah perangkat lunak sistem manajemen basis data SQL (DBMS) yang multithread, dan multi-user. MySQL adalah implementasi dari sistem manajemen basis data relasional (RDBMS). MySQL dibuah oleh TcX dan telah dipercaya mengelola sistem dengan 40 buah database berisi 10.000 tabel dan 500 di antaranya memiliki 7 juta baris. MySQL AB merupakan perusahaan komersial Swedia yang mensponsori dan yang memiliki MySQL. Pendiri MySQL AB adalah dua orang Swedia yang bernama David Axmark, Allan Larsson dan satu orang Finlandia bernama Michael "Monty". Setiap pengguna MySQL dapat menggunakannya secara bebas yang didistribusikan gratis dibawah lisensi GPL 
(General Public License) namun tidak boleh menjadikan produk turunan yang bersifat komersial.

Pada saat ini MySQL merupakan database server yang sangat terkenal di dunia, semua itu tak lain karena bahasa dasar yang digunakan untuk mengakses database yaitu SQL. SQL (Structured Query Language) pertama kali diterapkan pada sebuah proyek riset pada laboratorium riset San Jose, IBM yang bernama sistem R. Kemudian SQL juga dikembangan oleh Oracle, Informix dan Sybase. Dengan menggunakan SQL, proses pengaksesan database lebih user-friendly dibandingkan dengan yang lain, misalnya dBase atau Clipper karena mereka masih menggunakan perintah-perintah pemrograman murni SQL dapat digunakan secara berdiri sendiri maupun dilekatkan pada bahasa pemrograman seperti C, dan Delphi. (Rifai, 2013)

\section{Metodologi Penelitian}

Pada penelitian ini terdapat beberapa tahapan yang dilakukan untuk memecahkan rumusan masalah dan mencapai tujuan yang diinginkan pada perancangan sistem aplikasi perpustakaan ini. Dimulai dari observasi, survei di lokasi penelitian, serta dilanjutkan dengan pengumpulan data-data yang dibutuhkan. Beberapa hal itu dilakukan untuk mendapatkan hasil penelitian yang sesuai dengan yang diinginkan oleh kedua belah pihak, yaitu pihak peneliti dan pihak SMK ITABA.

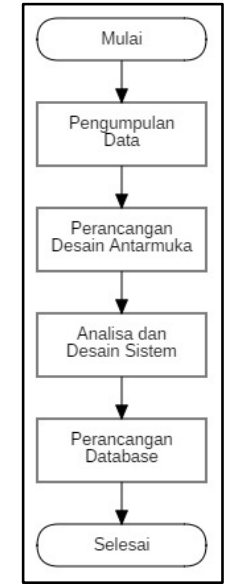

Gbr 1. Alur Penelitian

\section{A. Perancangan Desain Antarmuka}

\section{I.A.1 Perancangan Halaman Dashboard Admin}

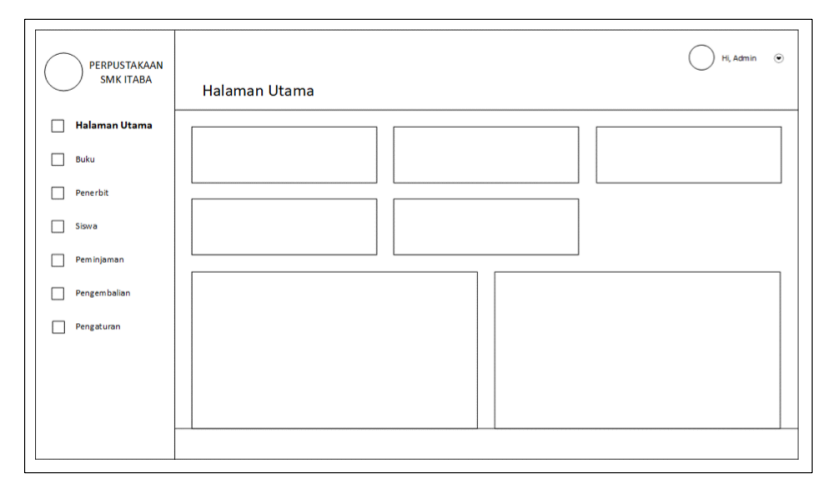

Gbr 2 Perancangan Halaman Dashboard Admin
Pada gambar 3.3 merupakan desain untuk tampilan halaman dashboard admin. Pada bagian atas halaman terdapat header yang berisi nama halaman dan nama user. Pada sisi kiri halaman terdapat navbar yang berisi logo beserta nama perpustakaan sekolah, dan daftar menu aplikasi. Menu yang terdapat pada navbar adalah halaman utama, buku, penerbit, siswa, peminjaman, pengembalian, dan pengaturan. Sedangkan pada bagian tengah halaman berisi pengumuman. Serta pada bagian bawah halaman terdapat footer.

\section{I.A.2 Halaman Menu Peminjaman}

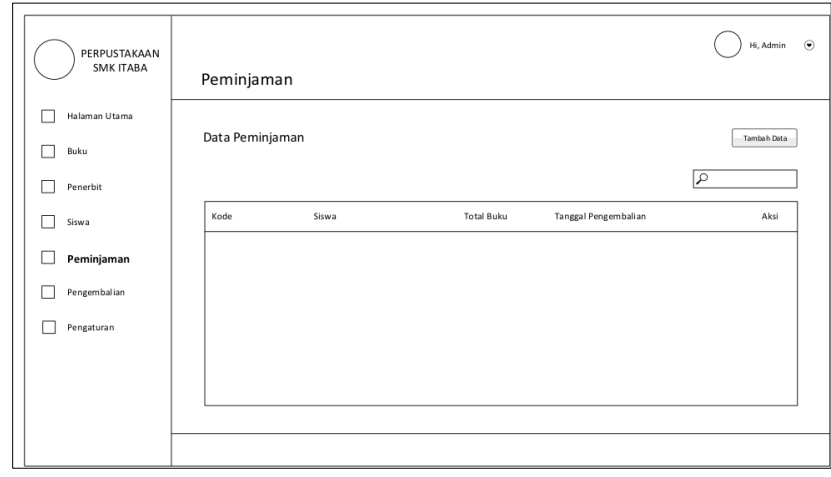

Gbr 3. Perancangan Halaman Menu Peminjaman

Pada gambar 2 merupakan desain untuk tampilan halaman menu peminjaman. Pada bagian atas halaman terdapat header yang berisi nama halaman dan nama user. Pada sisi kiri halaman terdapat navbar yang berisi logo beserta nama perpustakaan sekolah, dan daftar menu aplikasi. Sedangkan pada bagian tengah halaman berisi satu button tambah data, satu text box untuk pencarian data peminjaman, serta satu tabel yang berisi data-data peminjaman. Pada tabel terdapat kolom kode, siswa, total buku, tanggal pengembalian, dan aksi. Serta pada bagian bawah halaman terdapat footer.

\section{I.A.3 Halaman Menu Peminjaman}

\section{B. Perancangan Unified Modelling Language (UML)}

\section{I.B.1 Use Case Diagram}

Use case diagram merupakan pemodelan yang bertujuan untuk mendiskripsikan tipikal interaksi antar user dan sistemnya. Pada perancangan diagram use case ini, terdapat dua aktor yang memiliki peranan dalam sistem, yaitu Admin dan Siswa. Aktor Admin selaku pustakawan mempunyai peranan tertinggi dalam sistem. Pada gambar 3 akan dijelaskan hal apa saja yang bisa dilakukan aktor dalam sistem. 


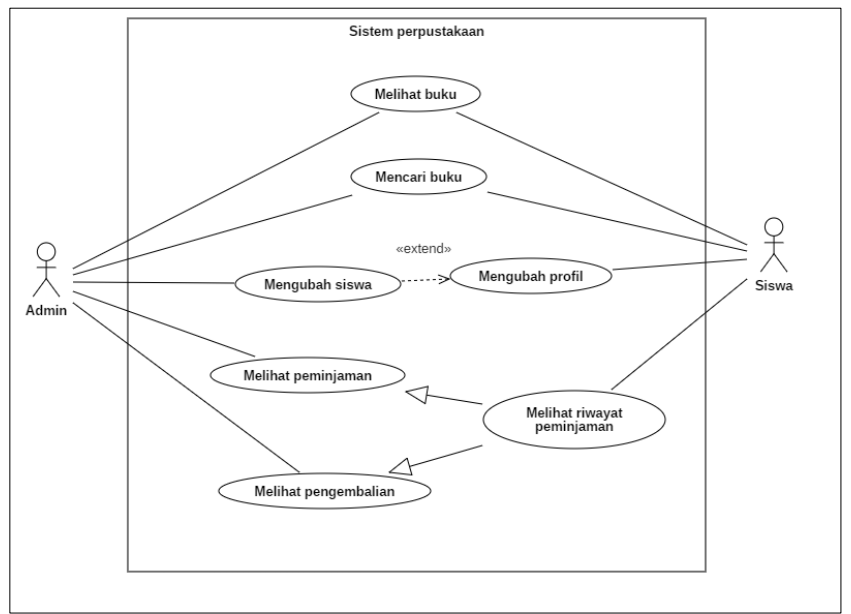

Gbr 4. Use Case Diagram Sistem Perpustakaan

Pada gambar 3 merupakan penggambaran use case diagram sistem. Dalam diagram tersebut terdapat tujuh use case yang saling berhubungan antara aktor admin dan siswa. tujuh use case tersebut adalah use case melihat buku dan mencari buku yang dapat diakses oleh kedua aktor, use case mengubah siswa yang dapat diakses oleh aktor admin mempunyai perpanjangan use case mengubah profil untuk aktor siswa. Use case melihat peminjaman dan melihat pengembalian yang dapat diakses aktor admin mempunyai turunan use case melihat riwayat peminjaman yang dapat diakses oleh aktor siswa.

\section{I.B.2 Activity Diagram}

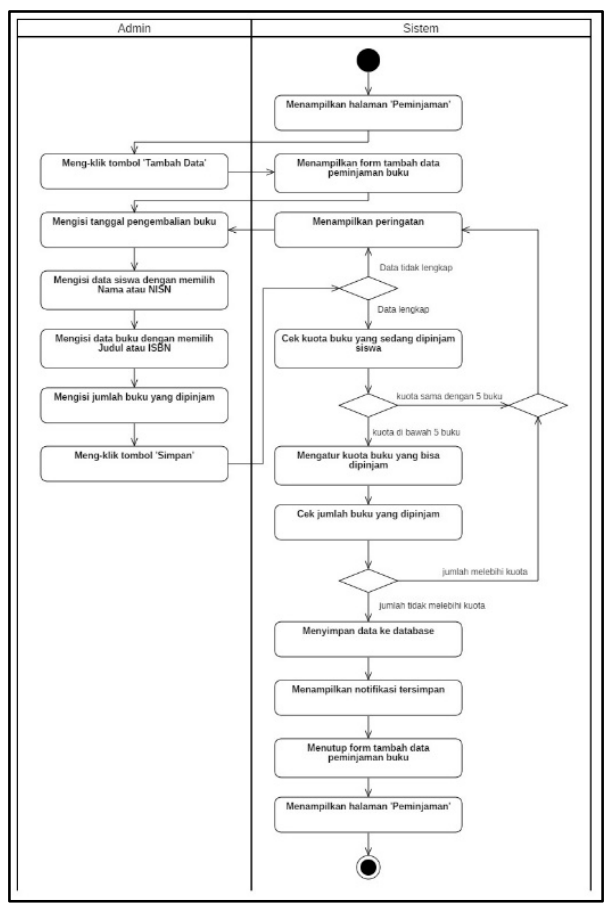

Gbr 5 Activity Diagram Tambah Data Peminjaman Oleh Admin

Pada Gambar 4 merupakan diagram aktifitas dari tambah data peminjaman buku pada halaman Peminjaman oleh admin terhadap sistem. Untuk bisa menjalankan aktifitas, dimulai dari Sistem menampilkan halaman Peminjaman, yang kemudian Admin memilih tombol Tambah Data. Sistem akan menampilkan form tambah data peminjaman buku untuk Admin mengisikan data peminjaman baru. Pada form tersebut, Admin memilih tanggal pengembalian buku, lalu mengisi data peminjam dengan memilih nama atau NISN siswa. Dilanjutkan dengan Admin mengisi data buku yang dipinjam dengan memilih judul atau ISBN buku, kemudian mengisi jumlah buku yang dipinjam tiap judul atau ISBN-nya. Setelah Admin memilih tombol Simpan, Sistem akan memproses apakah data peminjaman buku yang diisikan lengkap. Jika isian tidak lengkap, maka Sistem akan menampilkan peringatan untuk Admin melengkapi kembali data yang diperlukan. Jika isian lengkap, maka Sistem akan memeriksa kuota buku yang sedang dipinjam siswa. Jika kuota buku yang sedang dipinjam jumlahnya sama dengan 5, maka Sistem akan menampilkan peringatan peminjam telah melebihi limit. Jika kuota buku yang sedang dipinjam jumlahnya kurang dari 5, maka Sistem akan mengatur kuota buku yang bisa dipinjam. Setelah mengatur kuota buku, Sistem akan memeriksa kembali jumlah buku yang akan dipinjam siswa. Jika jumlah buku yang akan dipinjam melebihi kuota, maka Sistem akan menampilkan peringatan peminjam telah melebihi limit. Jika jumlah buku yang akan dipinjam kurang dari kuota, maka Sistem akan menyimpan ke database dilanjutkan dengan menampilkan notifikasi tersimpan. Lalu menutup form tambah data peminjaman buku dan menampilkan kembali Halaman Peminjaman.

\section{I.B.3 Class Diagram}

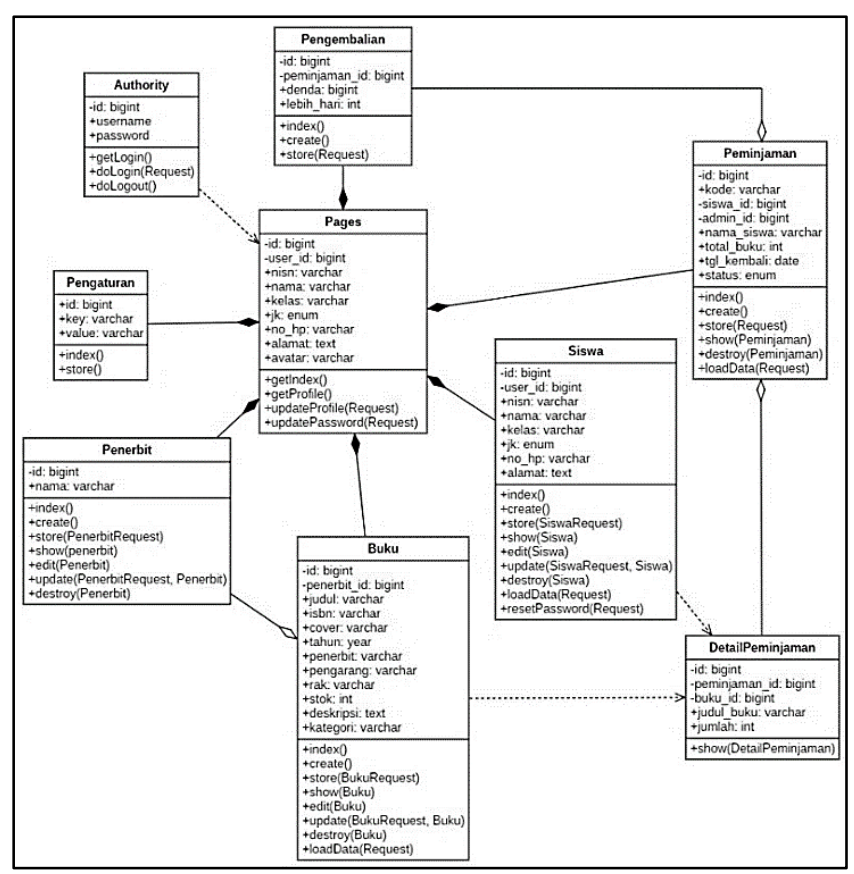

Gbr 6 Class Diagram Sistem Perpustakaan

Pada gambar 3.41 merupakan class diagram sistem perpustakan, terdapat sembilan class, yaitu Authority, Pages, Buku, Penerbit, Siswa, Peminjaman, Pengembalian, Pengaturan, dan DetailPeminjaman. Semua class diatas saling berhubungan langsung dengan class Pages, kecuali class DetailPeminjaman. Class DetailPeminjaman berhubungan 
langsung dengan class Peminjaman, Buku, dan Siswa. Antara class Penerbit dan class Buku mempunyai relasi aggregation yang bermakna bahwa class Penerbit merupakan bagian dari class Buku. Begitu juga pada class DetailPeminjaman terhadap class Peminjaman dan class Peminjaman terhadap class Pengembalian. Pada class Pengembalian terdapat relasi composition terhadap class Pages, yang bermakna bahwa class Pengembalian merupakan bagian dari class Pages. Yang membedakan dengan relasi aggregation adalah jika class Pages tidak ada maka class Pengembalian juga tidak ada. Class Pages juga memiliki relasi ini pada class Siswa, Buku, Penerbit, Pengaturan, dan Peminjaman. Relasi dependency ada diantara class Authority dengan class Pages, yang bermakna bahwa class Pages bergantung pada class Authority. Begitu pula class Buku dan class Siswa terhadap class DetailPeminjaman.

\section{I.B.4 Sequence Diagram}

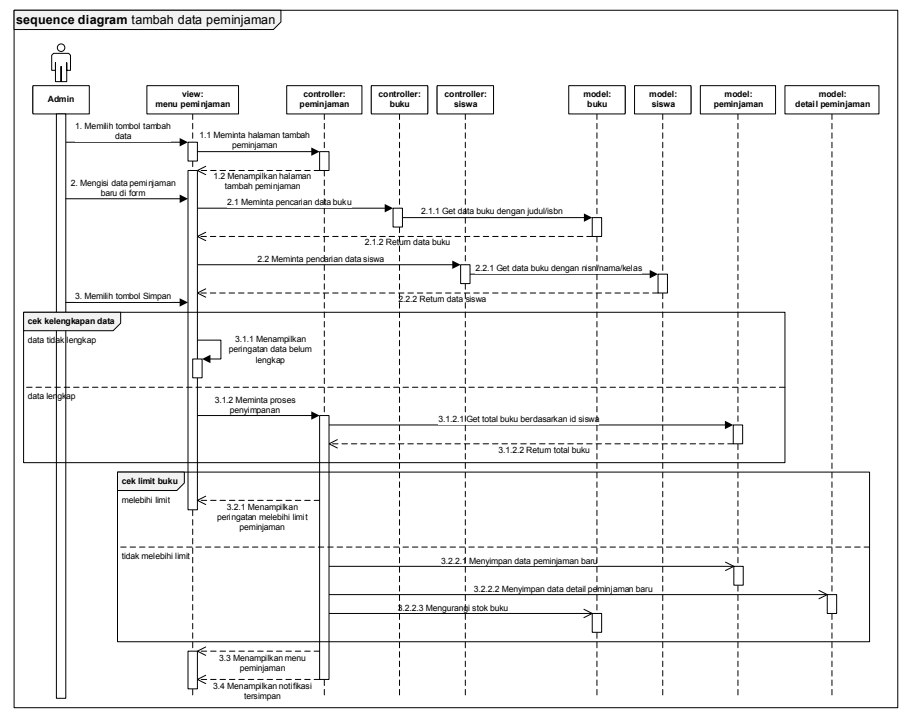

Gbr 7 Sequence Diagram Tambah Data Peminjaman oleh Admin

Pada gambar 3.54, merupakan sequence diagram yang menjelaskan urutan proses untuk tambah data peminjaman oleh admin. Proses dimulai dari admin sebagai aktor, terlebih dahulu memilih tombol tambah data pada view menu peminjaman yang kemudian diteruskan oleh view menu peminjaman ke controller peminjaman dengan meminta halaman tambah peminjaman untuk ditampilkan pada view yang kemudian admin mengisi data peminjaman baru pada view halaman tambah peminjaman. Saat memilih data buku, view halaman tambah peminjaman akan mengambil data buku ke model buku melalui controller buku. Saat memilih data siswa, view halaman tambah peminjaman akan mengambil data siswa ke model siswa melalui controller siswa.

Kemudian admin memilih tombol simpan pada view halaman tambah peminjaman yang memicu pemeriksaan kelengkapan data. Jika data tidak lengkap, maka pada form peminjaman akan menampilkan peringatan data belum lengkap dan proses berhenti. Jika data lengkap, maka form peminjaman akan meminta proses penyimpanan pada controller peminjaman yang kemudian melakukan cek limit buku. Jika melebihi limit, maka controller peminjaman akan menampilkan peringatan melebihi limit peminjaman dan proses berhenti. Jika tidak melebihi limit, maka controller peminjaman akan melakukan penyimpanan data baru pada dua model, yaitu data peminjaman pada model detail peminjaman, dan data detail peminjaman pada model peminjaman. Kemudian controller peminjaman akan mengurangi stok buku pada model buku dan mengalihkan ke view menu peminjaman dengan menampilkan notifikasi tersimpan.

\section{Perancangan Basis Data}

\section{I.C.1 Conceptual Data Model}

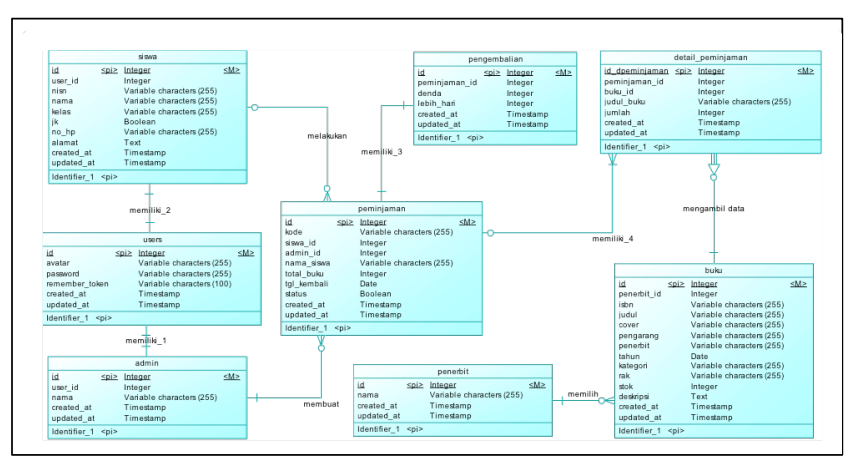

Gbr 8 Conceptual Data Model Basis Data Perpustakaan

Pada gambar 3.72, merupakan rancangan CDM pada basis data perpustakaan. Terdapat delapan tabel yang saling berhubungan.

a. Relasi one-to-one ada pada tabel user terhadap admin dan siswa, dan peminjaman terhadap pengembalian. Bermakna bahwa tiap satu user memiliki hanya satu admin, tiap satu admin memiliki hanya satu user. Begitu pula pada siswa, bahwa tiap satu user memiliki hanya satu siswa, tiap satu siswa memiliki hanya satu user. Dan pada peminjaman, bahwa tiap satu peminjaman memiliki hanya satu pengembalian, tiap satu pengembalian memiliki hanya satu peminjaman. Keempat tabel ini memiliki sifat mandatory terhadap satu sama lain.

b. Relasi one-to-many ada pada tabel siswa dan admin terhadap peminjaman, dan peminjaman terhadap detail peminjaman. Bermakna bahwa tiap satu siswa bisa memiliki satu atau banyak peminjaman, tiap peminjaman bisa jadi memiliki setidaknya satu siswa. Pada relasi peminjaman terhadap admin memiliki sifat mandatory, bermakna bahwa tiap satu admin bisa jadi memiliki satu atau banyak peminjaman, tiap satu peminjaman wajib memiliki hanya satu admin. Dan pada relasi peminjaman terhadap detail peminjaman bersifat mandatory, bermakna bahwa tiap satu peminjaman wajib memiliki satu atau banyak detail peminjaman, tiap detail peminjaman bisa jadi memiliki setidaknya satu peminjaman.

c. Relasi many-to-one ada pada tabel detail peminjaman terhadap buku, dan buku terhadapa penerbit. Pada relasi detail peminjaman terhadap buku memiliki sifat dependent, yang bermakna bahwa tiap satu detail peminjaman wajib memiliki 
hanya satu buku, tiap satu buku bisa jadi memiliki satu atau banyak detail peminjaman. Pada relasi buku terhadap penerbit memiliki sifat mandatory, bermakna bahwa tiap satu buku wajib memiliki hanya satu penerbit, tiap satu penerbit bisa jadi memiliki satu atau banyak buku.

\section{I.C.2 Physical Data Model}

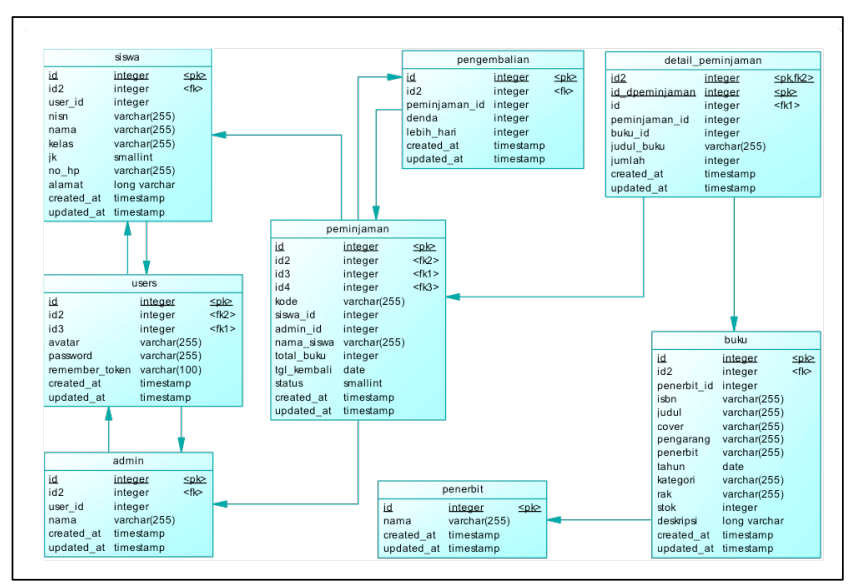

Gbr 9. Physical Data Model Basis Data Perpustakaan

Pada gambar 3.73, merupakan rancangan PDM pada basis data perpustakaan. Rancangan ini merupakan hasil dari generate CDM yang ada pada gambar 3.73. untuk jumlah tabel tidak berubah, namun beberapa atribut/index dalam beberapa tabel bertambah. Atribut/index tambahan ini bisa diketahui dari tag ' $<\mathrm{fk}>$ ' pada masing-masing atribut/index.

\section{HASIL DAN PEMBAHASAN}

Hasil dan pembahasan merupakan tahap pengembangan rancangan dari bab sebelumnya menjadi suatu perancangan aplikasi yang dapat bekerja sebagaimana mestinya. Dan melakukan uji coba terhadap perancangan aplikasi perpustakaan yang telah dibuat. Pada awal bagian ini dijabarkan spesifikasi perangkat keras dan lunak di mana program diimplementasikan.

\section{A. Implementasi Antarmuka}

Pada sub-bab ini merupakan hasil implementasi dari perancangan desain antarmuka yang telah dilakukan pada bab sebelumnya yaitu di sub-bab perancangan desain antarmuka.

\section{I.A.1 Antarmuka Dashboard Admin}

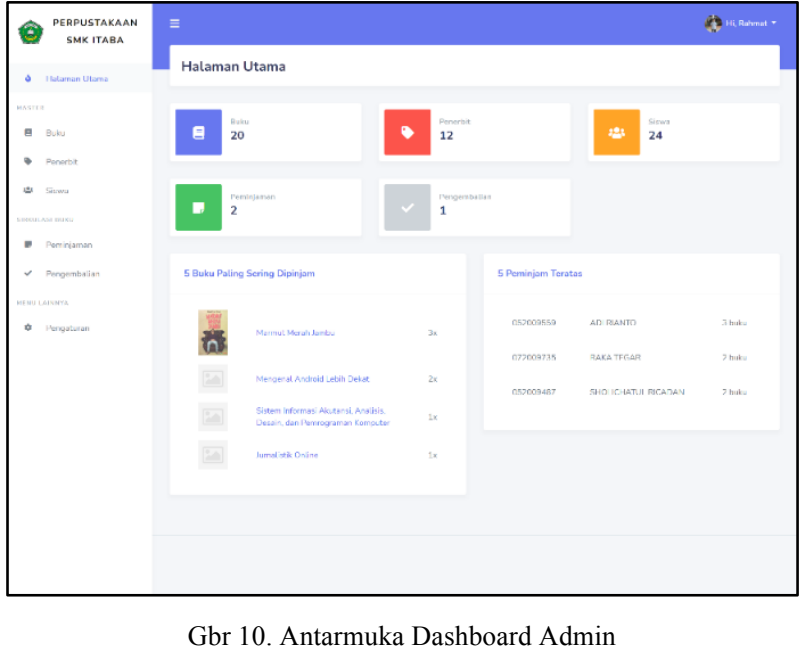

Pada gambar 4.2, merupakan tampilan halaman utama dari admin. Pada bagian tengah halaman menampilkan total data dari menu buku, penerbit, siswa, peminjaman, dan pengembalian. Terdapat juga dua kotak untuk menampilkan buku-buku terlaris dan siswa-siswa yang sering meminjam.

\section{I.A.2 Antarmuka Menu Peminjaman oleh Admin}

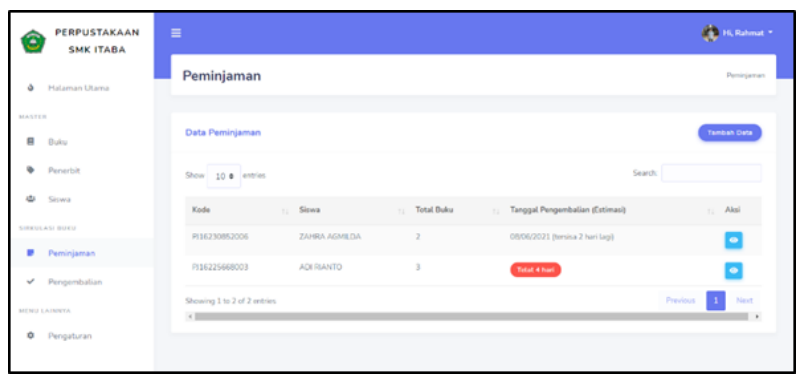

Gbr 11 Antarmuka Menu Peminjaman oleh Admin

Pada gambar 4.6, merupakan tampilan menu peminjaman. Halaman ini menampilkan tabel dengan isian data-data peminjaman dengan tombol aksi yang bisa dilakukan admin. Hanya terdapat satu aksi, yakni aksi untuk melihat detail peminjaman.

\section{I.A.3 Antarmuka Menu Pengembalian oleh Admin}

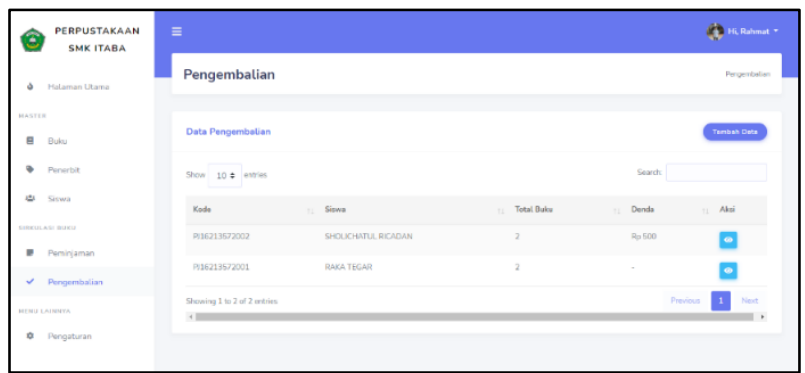

Gbr 12 Antarmuka Menu Pengembalian oleh Admin

Pada gambar 4.7, merupakan tampilan menu pengembalian. Halaman ini menampilkan tabel dengan isian data-data pengembalian dengan tombol aksi yang bisa dilakukan admin. Hanya terdapat satu aksi, yakni aksi untuk melihat detail pengembalian. 


\section{I.A.4 Antarmuka Menu Riwayat Peminjaman oleh Siswa}

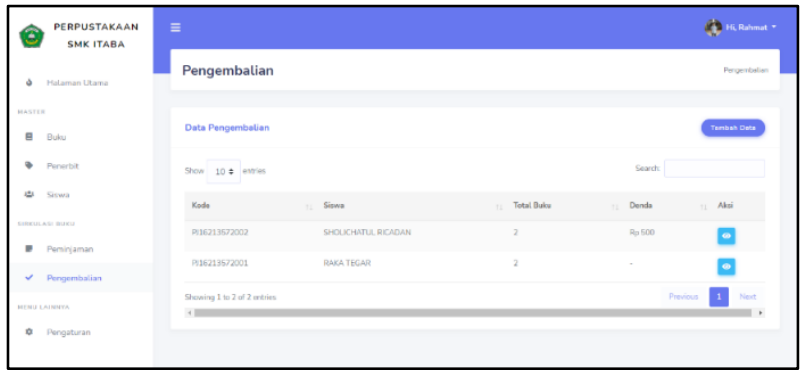

Gbr 13 Antarmuka Menu Pengembalian oleh Siswa

Pada gambar 4.12, merupakan tampilan menu riwayat peminjaman. Halaman ini menampilkan tabel dengan isian data-data peminjaman baik yang sedang dipinjam maupun sudah dikembalikan dengan tombol aksi yang bisa dilakukan siswa. Hanya terdapat satu aksi, yakni aksi untuk melihat detail peminjaman.

\section{KESIMPULAN DAN SARAN}

Berdasarkan hasil penelitian dan pengerjaan laporan tugas akhir yang berjudul "Perancangan Sistem Aplikasi Perpustakaan Berbasis Web di SMK ITABA Menggunakan Framework Laravel" maka penulis mencoba membuat suatu kesimpulan serta mengajukan beberapa saran yang berhubungan dengan pembahasan yang telah dikemukakan di bab-bab sebelumnya.

\section{A. Kesimpulan}

Kesimpulan yang dapat diambil dari laporan ini adalah Perancangan sistem aplikasi ini menggunakan framework Laravel yang dapat membantu pustakawan dalam pengelolaan perpustakaan. Pada perancangan ini, memiliki fitur-fitur seperti:

a. Mengelola data buku (koleksi buku perpustakaan)

b. Mengelola data siswa selaku anggota perpustakaan c. Mengelola sirkulasi buku, yaitu peminjaman dan pengembalian

Serta menggunakan MySQL sebagai penampungan data.

\section{B. Saran}

Berdasarkan kesimpulan yang telah dijelaskan di atas, maka penulis menyarankan untuk pengembangan penelitian yang akan datang sebagai berikut:

1. Aplikasi ini dapat dikembangkan lagi dengan penambahan fitur denda bagi peminjam yang tidak bisa mengembalikan buku (contoh: buku hilang)

2. Aplikasi ini dapat dikembangkan lagi dengan penambahan fitur untuk mengetahui siswa yang masih aktif dan siswa yang sudah lulus sekolah.

3. Aplikasi ini kedepannya dapat memiliki tampilan yang lebih interaktif.

\section{REFERENSI}

[1] Afliyanti, M. PERANCANGAN SISTEM INFORMASI PERPUSTAKAAN SMA NEGERI 1 DANAU KEMBAR. Padang, Sumatera Barat: Universitas Negeri Padang. 2014.

[2] Nugroho, A. Rekayasa Perangkat Lunak Menggunakan UML Dan Java . Yogyakarta. 2004

[3] Prawiro, A., Utomo, Y. B., \& Kusumastutie, D. A. Perancangan Sistem Informasi Perpustakaan di SMAN 1 Kedungwaru Tulungagung. Generation Journal Vol. 2, 73-82. 2018

[4] Prawiro, A., Utomo, Y. B., \& Kusumastutie, D. A. Perancangan Sistem Informasi Perpustakaan di SMAN 1 Kedungwaru Tulungagung. Generation Journal Vol. 2, 73-82. 2018

[5] Rohmah, N., Aryadita, H., \& Brata, A. H. Pengembangan Sistem Informasi Perpustakaan Berbasis Web Pada Perpustakaan Kecamatan Bungah. Jurnal Pengembangan Teknologi Informasi dan Ilmu Komputer Vol. 3 No. 3, 2225-2234. 2019

[6] Sari, U. M., \& Djuniharto. Sistem Informasi Perpustakaan Di SMK Gajah Mada Banyuwangi. Konferensi Nasional Sistem Informasi 2018 (pp. 442-448). Pangkalpinang: STMIK Atma Luhur Pangkalpinang. 2018.

[7] Wibowo, D. A., Riyanto, V., \& Rakhmah, S. N. Sistem Informasi Perpustakaan Berbasis Web pada SMK Negeri 2 Kota Bekasi. Jurnal Inkofar Vol. 1 No. 2, 41-50. 2017. 